\title{
NOTES ON SOME LITTLE-KNOWN RED ALGAL EPIPHYTES OF JAPAN
}

AUTHOR(S):

Cordero, Paciente A.

\section{CITATION:}

Cordero, Paciente A.. NOTES ON SOME LITTLE-KNOWN RED ALGAL EPIPHYTES OF JAPAN. PUBLICATIONS OF THE SETO MARINE BIOLOGICAL LABORATORY 1975, 22(5): 223-228

ISSUE DATE:

1975-11-29

URL:

http://hdl.handle.net/2433/175905

RIGHT: 


\title{
NOTES ON SOME LITTLE-KNOWN RED ALGAL EPIPHYTES OF JAPAN ${ }^{1}$
}

\author{
Paciente A. CORDERO, $\mathrm{Jr}^{2)}$ \\ Seto Marine Biological Laboratory
}

With Text-figures 1-5

Studies on one drift macro-alga collected in the winter of 1973, from southern Japan have brought to light several interesting epiphytic algae. This work provides additional distributional record for Japan.

Presented in this paper are three algal epiphytes, namely, Antithamnion lherminieri (Crouan) Bornet, Ceramium howei Weber van Bosse and Ceramium tenerrimum (Martens) Okamura. These algae were observed attached to a common host, Sargassum sp., stranded on the shore of Fukiage, Kagoshima Prefecture.

The materials used in this study are mounted in glycerine micro-slides and presently kept with the author in the Seto Marine Biological Laboratory.

\section{Description}

RHODOPHYTA

\section{Antithamnion NAEGELI 1847}

\section{Antithamnion lherminieri (Crouan) Bornet.}

(Figs. 1-2)

Nasr 1941: 66, figs. 9-10; Dawson 1956: 46, Dawson 1959: 46; Dawson 1962: 18, pl. 5, fig. 5; Itono 1969: 35, fig. 4 A-C.

Antithamnion antillanum Bocrgesen, 1917: 145, figs. 213-216; Tanaka \& Itono 1972: 70.

Callithamnion lherminieri Crouan \& Crouan, in Maze et Schramm 1870-1877: 144.

Japanese name: Nise Kinuitogusa

Habitat: On Sargassum sp., together with the two Ceramia species listed below, Fukiage, SE Kagoshima. PAC-JW-1973-116 (2 slides), collected by P.A. Cordero, Jr., 29 Dec. 1973.

Type: Collected from the Red Sea, presently kept in the Thuret et Bornet

1) Contributions from the Seto Marine Biological Laboratory, No. 595.

2) Office Address: National Museum of the Philippines, Rizal Park, Manila, PHILIPPINES.

Present Address: Seto Marine Biological Laboratory, Kyoto University, Shirahama, Wakayama Prefecture.

Publ. Seto Mar. Biol. Lab., XXII (5), 223-228, $1975 . \quad$ (Article 14) 


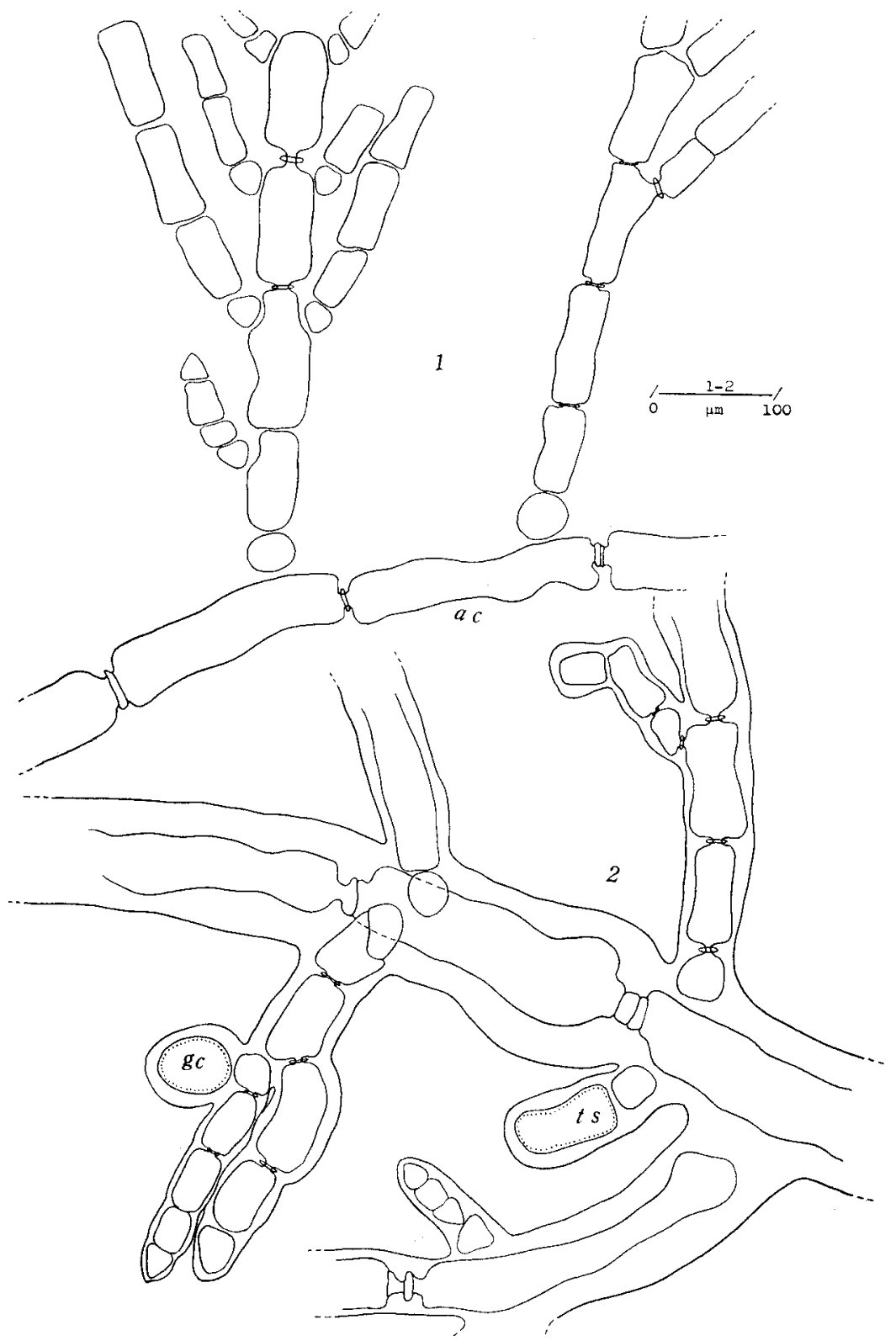

Figs. 1-2. Antithamnion lherminieri (Crouan) Bornet

1. Upper part of indeterminate axis.

2. Mid-basal part of indeterminate axis with gland cell and undivided tetraspore. Abbreviations Used in the Figures - ac: axial cell; ah: apical hair; cc: cortical cell; gc: gland cell; ts: tetrasporangium. 
Herbarium, Paris Natural History Museum.

Geographical distribution: Red Sea (Nasr, 1941); Guadeloupe (Maze \& Schramm, 1870-1877); West Indies (Boergesen, 1917); Marshall Islands (Dawson, 1956); Palmyra Atoll (Dawson, 1959); Pacific Mexico (Dawson, 1962); Amami and Yonakuni Islands (Itono, 1969).

Plants small, delicate, barely $0.5 \mathrm{~cm}$ tall; rhizoidal organ disk-shaped, uniseriate; prostrate axis usually less than $50 \mu \mathrm{m}$ in diameter, of cells 3-5 diameter long, giving rise to vertical branches and opposite, short branches; vertical branches to $3 \mathrm{~mm}$ high $(-5 \mathrm{~mm})$, bearing alternate branchlets from every cell, of cells 2-3 times as long as broad; tip of branch bluntish, ascending; branchlets simple but may bear as much as two additional branchlets; rhizoids solitary, lobed, digitately emanating from basal cells of dwarfish branchlets ventrally oriented; gland cells infrequent, when present usually resting on one cell on the branchlets, ovoid, to $10 \mu \mathrm{m}$ broad; tetrasporangia located near the base on the adaxial side of lateral branchlets, subcylindrical, sessile, cruciately divided, becoming broader apically, to $90 \mu \mathrm{m}$ long and $45 \mu \mathrm{m}$ broad, thickly walled; sexual reproductive features not oberved.

The strong resemblance of this species with Ant. antillanum, prompted Nasr (1941) to say that, "the author (Nasr) suggests Guadeloup plant the variety typica and the West Indian plant the variety antillanum Boerg. com. nov."

However, my observations on the present Japanese plant reveal some of the characters by which Boergesen (1917) delimited his new species from Ant. cruciatum. The manner of branching, position of gland cell and shape and location of tetrasporangia in the material at hand are distinctinve enough to regard it identical with Boergesen's Dutch West Indies species. Following, therefore, Nasr's opinion it would seem that the Japanese material falls clearly under var. antillanum.

Itono's (1969) illustrations specially Fig. 4 B-C and description of his southern Japanese plants reported as Ant. lherminieri, seem to be in close accord with ours.

\section{Ceramium ROTH 1797}

\section{Ceramium howei Weber van Bosse.}

(Figs 3-4)

1923: 323, fig. 16; Tanaka \& Pham-Hoang 1962: 36, fig. 12 A-C.

Japanese name: Nansei-igisu (Cordero) nom. nov.

Habitat: PAC-JW-1973-115, with the same field notes as the above species.

Type: unknown to this writer, probably in Leiden?

Geographical distribution: Warm Pacific.

Plant rather low barely $5 \mathrm{~mm}$ in height, growing on Sargassum sp.; main filaments irregularly branched, to $100 \mu \mathrm{m}$ or more in diameter, bearing secundate branchlets; nodal constrictions usually not prominent, internode becoming shorter upwardly; cortical coatings, of cells longitudinally arranged, compact apically and lax basally; 
tetrasporangia borne by stichidia-like branches, tetraspores embedded in cortical cells, 15-20 $\mu \mathrm{m}$ across, oftentimes scattered or may appear in row (s) or even whorled.

A comparison with the original description of Weber van Bosse (1923) as well as an examination of the beautifully illustrated Vietnamese plant of Tanaka and Pham-Hoang (1962), shows some similar features with the plants at hand. Some of

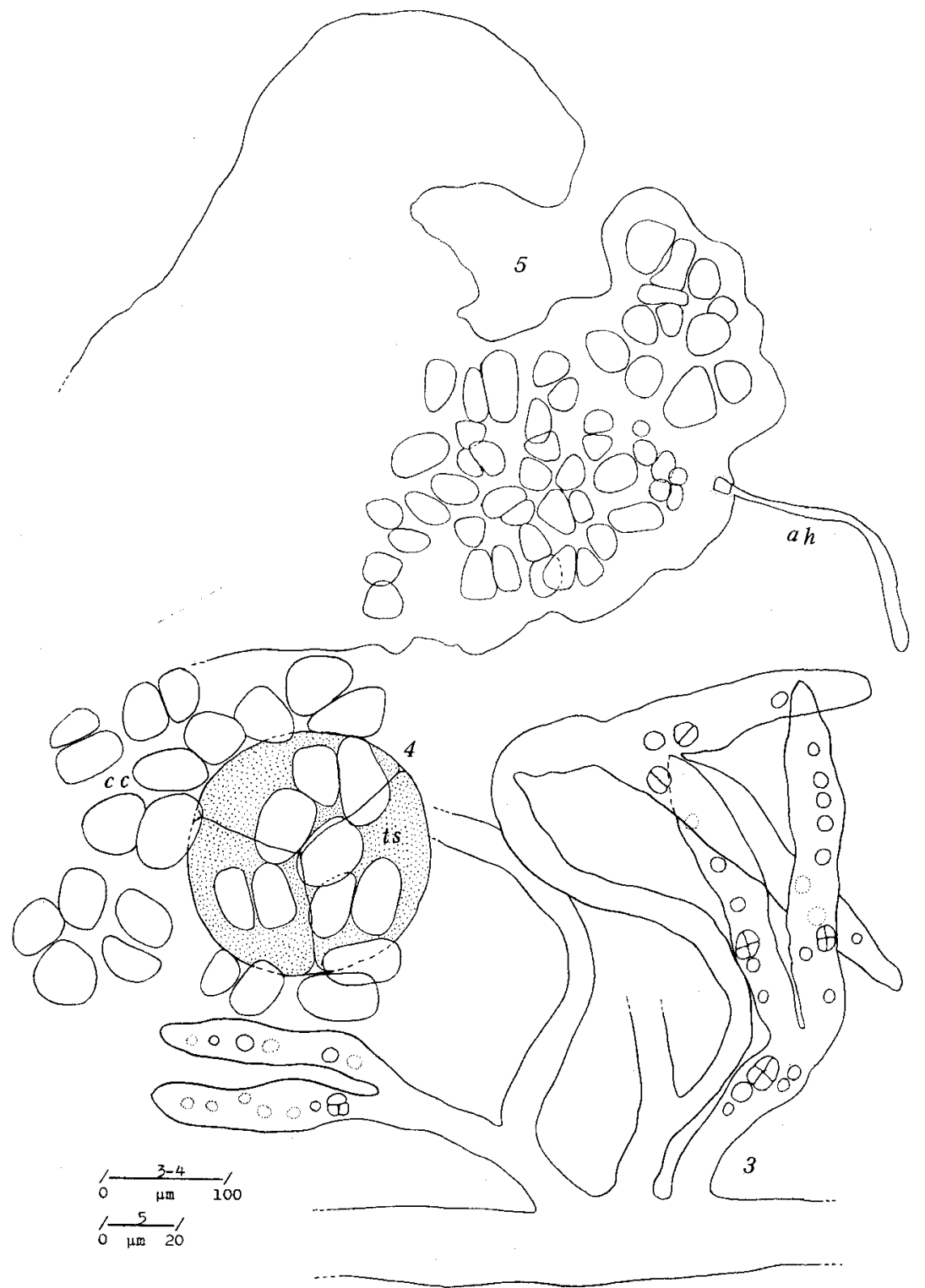

Figs. 3-4. Ceramium howei Weber van Bosse

3. Tetrasporophytic plant.

4. Surface section of thallus showing cortical cells with immersed tetraspore.

Fig. 5. Ceramium tenerrimum (Martens) Okamura. Forcipate apex bearing apical hair. 
the minor variations are height, their's (later) $2-4 \mathrm{~mm}$ long, main axes being a little larger, cortical cells in clear longitudinal chain, and tetrasporangia arranged in 1-3 rows; the last is rather uncommon in the present Japanese materials.

\section{Ceramium tenerrimum (Martens) Okamura.}

(Fig. 5)

1921: 112, pl. 179, figs. 1-7; Okamura 1936: 736; Nakanura 1954: 15 (in partim); Segawa 1956: 105, pl. 63, fig. 497; Nakamura 1965: 133, pl. 1, 4; fig. 5; Segawa 1930: 86; Konno \& Noda 1974: 85. Hormoceras tenerrimum Martens, "1866: 146, t. VIII, fig. 2 (Type locality, Nagasaki, IV, 1861, Schottmuller)", quoted from Nakamura 1965: 133.

Hor. flaccidum Suringar (non Harvey), "1870: 28, tab. XIII."

Ceramium gracillimum Okamura (non Griffiths and Harvey), "1902: 83".

Japanese name: Ke-igisu.

Habitat: PAC-JW-1973-117, with the same field notes as the above species.

Geographical distribution: Mediterranean Sea; Indo-Pacific Ocean.

Thalli epiphytic, creeping on host, to $5 \mathrm{~mm}$ long, consisting of dichotomously ramified cylindrical axes; axes to $120 \mu \mathrm{m}$ in diameter, showing incomplete cortication; cortical cells smaller above becoming larger below; nodes entire, constrictions not superficially evident except apically, internode two-times longer than broad, decidedly longer near mid-basal portion of main axes/filaments; internode oftentimes coated with minute coloured cells of various sizes. Dichotomous branches bearing pronounced irregular, second lateral proliferous growths; tips in-curved oftentimes 'touching each other', occasionally issuing one- to two or more celled colorless hair; hair supported by small, quadrate basal cell; tetraspores, nodal and dividing cruciately, to $100 \mu \mathrm{m}$ across.

Our findings duplicate those that have been previously reported based on Japanese materials, except for very minor variations in the dimension of the vegetative and reproductive parts.

\section{Summary}

Three species of epiphytic red algae, members of Family Ceramiaceae, are given. The first, Antithamnion lherminieri (Crouan) Bornet, has so far been reported from southern Japan; second, Ceramium howei Weber van Bosse, is proposed as new record to Japan; and the third, Ceramium tenerrimum (Martens) Okamura, is the most common species among the three having been reported from both coasts of Japan. These epiphytes were found growing on a species of Sargassum.

\section{Acknowledgements}

The writer is grateful to the many Japanese phycologists whose interests in reviewing and offering valuable suggestions as well as access to their private libraries and loan of specimens, are indeed worthy of special acknowledgement; and, the Philippine Government thru its National Museum for granting me a singular privilege 
to further my research on marine phycology in Japan, the second time around.

\section{LITERATURE GITED}

Boergesen, F.T. 1917. The marine algae of the Danish West Indies, Rhodophyceae. Dansk. Bot. Arkiv., 3 (1f): 369-504. Copenhagen.

Dawson, E.Y. 1956. Some marine algae of the Southern Marshall Islands. Pac. Sci. 10(1): 25-66. 1956. Changes in Palmyra Atoll and its Vegetation through the activities of Man, 19131958. Pac. Naturalist 1(2): 1-52.

1962. Marine Red Algae of Pacific Mexico, Part 7, Ceramiales, Ceramiaceae, Delesseriaceae. 1-207 pp., Univ. South. Calif. Press, Los Angeles, California.

Itono, H. 1969. The Genus Antithamnion (Ceramiaceae) in Southern Japan and Adjacent waters-I. Mem. Fac. Fish. Kagoshima Univ., 18: 29-45, 7 text-figs.

Konno, K, and M. Noda 1974. On the species of Ceramium Roth from the coast of Akita Prefecture facing the Japan Sea. Sci. Rep. Niigata Univ., Ser. D. (Biology), No. 11: 81-87.

Maze, H. and A. Schramm 1870-1877. Essai de Classification des algues de la Guadeloup. xix +283 (Bosse-Terre, Guadeloup).

Nakamura, Y. 1954. The Structure and Reproduction of the Genera Ceramium and Campylaephora in Japan with special Reference to Criteria of Classification. Sci. Pap. Inst. Alg. Res., Fac. Sci. Hokkaido Univ., 4(1): 15-62. 1965. Species of the Genera Ceramiun and Campylaephora, Especially those of Northern Japan. Ibid, 5(2): 119-180, $15 \mathrm{pls}$.

Nasr, A.H. 1941. Some new and little known algae from the Red Sea. Rev. Algol. 12: 57-76.

Okamura, K. 1921. Icones of Japanese Algae, IV, 1-205, pls. 151-200 (Published by the author) Tokyo.

1936. Nippon Kaiso shi. 964 pp. Tokyo.

Segawa, S. 1930. On the marine algae of Susaki, Prov. Idzu, and its vicinity. Sci. Pap. Inst. Alg. Res. Fac. Sci., Hokkaido Imp. Univ. I(1): 59-90, pls. 19-20.

Tanaka, T. and Pham-Hoang Ho. 1962. Notes on Some Marine Algae from Vietnam-I. Mem. Fac. Fish. Kagoshima Univ., 11(1): 24-40, 14 text-figs.

and H. Itono. 1972. The Marine Algae from the Island Yonaguni--II. Ibid, 21(1): 1-14, 5 text-figs.

Weber van Bosse, A. 1923. Liste des algues du Siboga, III. Rhodophyceae. 2: 311-392, 2 pls. 